\title{
Is She a Pawn, Prodigy or Person with a Message? Public Responses to a Child's Political Speech
}

\author{
REBECCA RABY \\ MARY-Beth RADDON
}

\begin{abstract}
The 2012 appearance on YouTube of a speech about banking reform prompted mainstream news coverage and hundreds of online comments, dwelling less on the content of the speech than on the speaker, Victoria Grant, a twelve year-old girl. A qualitative content analysis of over 600 comments revealed disagreement about children's capacities as participants in political and economic discussions. Commenters' mixed beliefs were linked to dominant, frequently contradictory, discourses of childhood. Victoria Grant was positioned as embedded in educational processes, as competent but often exceptional, as incompetent, and as innocent and therefore vulnerable. These conflicting yet emotionally charged narratives of childhood illustrate the concept's rhetorical elasticity and flexibility. Despite advances in the cause of children's social participation in recent years, most of these adult-centered narratives undermine the idea of children as legitimate contributors to economic analysis and political debate.
\end{abstract}

Keywords: discourses of childhood, children's agency, children's participation, child public speaking, banking reform, qualitative media analysis

Résumé. La parution en 2012 sur YouTube d'un discours sur la réforme bancaire a attiré l'attention des médias et suscité des centaines de commentaires sur Internet, non pas tant en raison de sa teneur, mais du fait que son auteur était Victoria Grant, une fille de douze ans. Une analyse qualitative du contenu de plus de 600 commentaires a permis de constater des divergences d'opinions sur l'aptitude des enfants à participer à des débats politiques et économiques. $\mathrm{La}$ perplexité des commentateurs reflétait bien le débat dominant souvent contradictoire sur l'enfance. On représentait Victoria Grant comme le fruit du système éducatif, comme compétente mais souvent exceptionnelle, comme incompétente ou comme naïve et de ce fait vulnérable. Ces descriptions de l'enfance aussi contradictoires que chargées d'émotions illustrent la souplesse rhétorique de ce concept. Malgré les avancées récentes des promoteurs de la participation des enfants au débat social, la plupart de ces commentaires adulto-centriques sapent 
la notion voulant que les enfants soient des interlocuteurs valables dans l'analyse économique et le débat politique.

Mots clés: débat sur l'enfance, organismes d'aide à l'enfance, participation des enfants, discours public des enfants, réforme bancaire, analyse qualitative des médias

\section{INTRODUCTION}

an children be taken seriously when they are contributing to political yor economic discussions? A public debate erupted on this question in May 2012 when the video of a political speech by twelve-year-old Victoria Grant "went viral" on YouTube and then became a story for two major Canadian news organizations. This social media attention and news media spotlight brought into focus contradictory beliefs about the capacities of children and their status as political subjects.

Originally a grade six public speaking project, Victoria Grant's speech was video-recorded at the Public Banking in America Conference in Philadelphia, where she argued that the Canadian government should stop borrowing from private banks at commercial interest rates and instead restore the Bank of Canada to the national lending role it served prior to the 1970s. The ensuing news stories and responding commentaries dwelt less on the content of the speech, however, than on Victoria Grant herself, a white, private-schooled twelve-year-old from Cambridge, Ontario, and on the question of whether a child can call for banking reform. We, too, address these audience preoccupations with Victoria Grant's age and gender to understand how her reception as a girl interacted with her capacity to deliver a political message.

The responses to Victoria Grant's speech, in hundreds of comments following several YouTube postings and online news stories by the CBC and Huffington Post, reflect dominant and competing discourses of childhood, including many which challenge the idea of children as participants, despite recent advances in the cause of children's participation (Lansdown 2010; Reynaert, Bourverne-de Bie and Vandevelve 2009). Fundamentally, Victoria Grant's story is about whether children can be considered competent contributors to political debate, with views worthy of adult ears. Our analysis reveals how discourses of what it means to be a child, including concerns about innocence and protection from exploitation, produce children as able or unable to speak on political issues. We argue that beliefs about the basis for legitimate authority to participate politically, e.g. life experience or education, support or limit chil- 
dren being seen as able to comment. By analyzing the varied responses to Victoria Grant, we expose adult-centric understandings of children's contributions to political discussions, the absence of advocacy for children's rights to participation in public conversation, and how elastic the concept of child can be when deployed strategically to support the political stance of an adult.

\section{Children's Political Participation, Citizenship and Agency}

The last three decades have seen a significant rise in advocacy for children's participation in decision-making, especially in the United Kingdom, Europe and Australia. Many advocates contend that children are not simply growing up to be something in the future but have viewpoints, insights and contributions in the present that shape the world around them and that should be recognized and taken seriously (e.g. see James 2009; Wyness 2006; Kehily 2004). Numerous popular, governmental, and academic initiatives have now arisen to promote, foster, and invite children's participation across domains (e.g. see Reynaert et al. 2009), including research (e.g., see Christensen and James 2008) and policy-making (Reynaert et al. 2009).

Children's participation in general, and in political or economic spheres in particular, is not a transparently easy idea, however, despite the significant influence of Article 12 of the United Nations Convention on the Rights of the Child (UNCRC) and this extensive publishing and policy-making. Many adults (and children also) believe that children cannot, or should not, participate in dialogue or decision-making (see Lansdown 2010), in part due to the prevailing understanding of children as primarily innocent and "becoming" (Wyness et al. 2004). Despite critique and complication of the concept (e.g. Robinson 2013), children's innocence, linked to their perceived and relative lack of experience, and their vulnerability, trust, and imaginative, playful capacities, remains "a core feature of childhood" (Wyness et al. 2004: 85). This conceptualization of innocence does not accord with the economic, rational self-interest that is often associated with participatory citizenship (Lister 2007; Roche 1999), and political subjectivity especially (Zelizer 2005). Innocence, in turn, elicits a need for protection, which can limit children's knowledge, freedom, and consequent participation (e.g. see Robinson 2013, Johnny 2006) ${ }^{1}$. Discourses of children as "becoming" are

1. Not all see participation and protection as mutually exclusive, however. For example, Stasiulis (2002) suggests that through their participation, children advocate for issues related to their own protection. 
embedded in many developmental and socialization perspectives which emphasize that children are gradually gaining the skills, capacities and cultural knowledge that will eventually position them as capable adults (Woodhead 2005; Prout and James 1997). "Becoming" can resonate with childhood innocence, suggesting that young people are only gradually gaining capacities and understanding of the world around them, yet children's gradual exposure to knowledge and experience can also be seen to disrupt innocence. Both frameworks for understanding childhood are tenacious, but clearly not without criticism, as they tend to position children as incomplete and thus inferior to adults, to be selectively applied to some children over others, to homogenize diverse children's experiences, and relatedly, to privilege Western developmental processes (e.g., favouring individualism) and values (see Woodhead 2005; Burman 2001; Lee 2001; Walkerdine 1993).

Even among advocates for children's participation, challenges have been identified. Some are concerned with tokenism, for instance, with children only consulted or heard in fleeting, superficial ways (Lansdown 2001). Others are concerned with children's unequal power, the exclusion of more marginalized children from policy making (Black 2011) and the little impact that children have had on policy, even where they have been consulted (Reynaert et al. 2009). Others, including Reynaert et al. (2009), Millei (2010), Pongratz (2007), and Masscheliein and Quaghebeur (2005) contend that age-based inequality ensures that children's participation in institutional settings is in fact a technology that deepens their governance.

Children's participation, in political conversations and well beyond, has largely been discussed, and problematized, through the concepts of citizenship and agency. Citizenship is a political, contractual concept associated with concomitant rights that include recognized and legitimized participation in the public sphere. It is also a concept that has excluded children (Lister 2007; Wyness et al. 2004). Historically, citizenship has been premised on economic independence and the associated rights and responsibilities of public life, and yet Western children (and in various times and places, women and other marginalized groups) have been assumed to be outside "this network of mutual obligations" (Wyness et al. 2004: 84), particularly since the $19^{\text {th }}$ century (Zelizer 2005). Instead, children have tended to be associated with the private sphere of the home, a sphere of dependency (Such and Walker 2005; Wyness et al. 2004; Roche 1999). Overall, citizenship and associated rights are often predicated on the problematic assumption of a rational, independent and autonomous self that is only thought to come with adulthood. Reflecting a developmental emphasis, the citizenship literature has tended to see 
children as citizen adults in-the-making, rather than people with the requisite knowledge, input and responsibility in the present (Lister 2007, Roche 1999), a perception that is ironically confirmed through their immediate lack of recognition and participation (Wyness et al. 2004).

In response, advocates have sought to redefine both childhood and citizenship (e.g. Lister 2007; Roche 1999). Instead of focusing on their protection and control, Roche argues "that children be seen as members of society too, with a legitimate and valuable voice and perspective" (479). Highlighting children's existent responsibilities in particular, Roche argues for children's "partial citizenship" which recognizes the contested, shifting and uneven nature of citizenship, particularly for children who span a range of ages. Larkins (2014) similarly wishes to reconceptualize citizenship to focus on socially interdependent practices and relationships because here we can see that children are "participating social actors" (9). She documents a number of activities that diverse, marginalized children do and see as their own participation, to advocate for expanding our thinking about citizenship. Lister (2007) also considers children to be diversely located, "participating citizens" in a "citizenship community." She contends that children should be genuinely included for good decision-making, with adults listening to, and respecting, them. Ultimately Lister (2007) argues that we should not focus exclusively on rights, but on citizenship practices, which constitute children as citizens who tend to act as citizens, much like Victoria Grant, before being formally recognized as such. These researchers all point to young people's participation as already present in multiple activities, including everyday practices (see also Kallio and Häkli 2011).

The idea of children's partial participatory rights predates the UNCRC, but has been solidified through it. Article 12, for example, is considered a primary basis for recognizing children's "evolving capacities" as participatory citizens, positioning children as gradually developing, agentic, interested social participants who should be consulted (Stasiulis 2002; Roche 1999). Yet this rights discourse has also raised concern as it seems to prioritize decontextualized, individualized autonomy (Reynaert et al. 2009). Reynaert et al. (2009) are particularly troubled by the overall preoccupation with child competence, autonomy and independence in some children's rights literature, raising concerns that children may be increasingly made responsible for their actions, and without attention to context. The above calls for rethinking citizenship, for instance, are supported with reference to children's competencies and responsibilities. That said, the above-cited attempts to redefine citizenship also challenge the idea of an autonomous, rights-bearing subject by acknowledging interdependency and interaction. 
Finally, there are theoretical debates around what is meant by participation as it relates to children's agency (e.g. see Raby 2014; Imre and Millei 2010; Vandenbroaek and Bourverne-de-Bie 2006). Advocates for children's participation have sought to assert that rather than passive, gradual "becomings" who are subject to one-way socialization, children are social actors with agency: embedded in social structure but also participants in transforming social structure (James 2009). As we have outlined, researchers such as Roche (1999) and Lister (2007), argue that children are already social actors and that this needs to be recognized in reconfigurations of citizenship, for example. Agency can also be conceptualized as something that is bestowed, e.g. as subjects of rights, a position suggested through the $\mathrm{UNCRC}^{2}$. In another example, Such and Walker (2005) are concerned that children are only considered responsible when they are involved in anti-social behaviour, suggesting that children are only "granted agency and autonomy in the context of wrong-doing: children are able to be willfully irresponsible but not willfully responsible" (46). Ironically, when children then act, they are often seen as more like adults and denied protection (Stasiulis 2002).

Agency can also be talked about in terms of discourse, challenging the notion of a self-willed, autonomous modernist subject. Butler (1992, 1997), Davies (1990), and Laws and Davies (2000) argue that agency can be conceptualized within a poststructural understanding of the discursively produced subject wherein "some discursive practices constitute some speakers as agents" (Davies 1990:345). Discourse can be understood here as the culturally shared, interconnected (but also unstable) beliefs, representations, and statements about a particular thing, event or concept, that produce that particular thing, event, or concept (Burr 1995). A focus on discourse does not mean that people are straight-jacketed by discourse, however. Indeed, Butler sees the unstable subject as necessary for agency (1992). Both Davies (1990) and Laws and Davies (1997) argue that we can move beyond the terms of our emergence, seeing how discourse produces us as subjects, critiquing and evaluating these discourses, and using one discourse to counter another (Davies 1990; Laws and Davies 2000). People can similarly weigh the effects of discourses in terms of how they construct us and others, including young people. As Taylor states: "it is through the subject's discursive agency, that the possibility of doing things differently, of acting purposefully to subvert established practices, of

2. In contrast, Skott-Myhre and Tarulli contend that we cannot "give" children rights; instead rights are "self-produced by the very subjects to whom such rights are attributed" (2008: 70), which is evident in children's resistances and creative capacities. 
mounting insurrections, and of inscribing political acts in the social field, is made possible" $(2011 ; 827)$. In this sense, we can identify and note the productive effects of dominant popular discourses of childhood, such as innocence or becoming. Similarly, children's participation is, in itself, another discourse of childhood that can be produced, or negated, and one with effects in terms of how children are treated and how they think about themselves.

In this paper our beginning position is two-fold: that young people, like all of us, are participants in social interaction, producing and reproducing social meaning through that interaction. As such, we favour a discourse of children's participation and we agree with researchers, such as Roche (1991) and Kallio and Häkli (2011), who argue that children are, already, social actors. However, whether people consider themselves and others to be social actors or not, and whether our language and practices produce such an idea, is contingent on discourse. In this article we thus reflect on how discourses of childhood, as deployed in on-line comments responding to Victoria Grant's speech, intersect, diverge, and frame children as possible social participants, or not. These discourses thus work as social truths and yet also become open to evaluation as they are contradictory, and as they are used rhetorically in political arguments both about banking reform and about children's capacities to speak on banking reform. These deployments position children (sometimes all children, and sometimes specifically girl children) as being either legitimate or illegitimate participants in public debate of economic issues, and concomitantly work as rhetorical strategies that bolster the authority of adult voices.

\section{Methods}

Methodologically, our study draws on traditions of news media analysis (Gruber 2008; Altheide and Schneider 2013) and engages with emerging conventions in the study of computer-mediated communication, particularly the interactive capabilities of websites, which create the possibility for user-generated comments. For researchers interested in discourse analysis, user-generated comments allow for the study of competing claims, divergent representations, and various strategies of persuasion in public debate (Park 2013). Online forums allow for relatively easy participation in news commentary by those with internet access. Comments on online news sites are well read (Lee 2012), and commenters frequently respond to other users' comments. 
User-generated comments cannot be taken as a direct gauge of public opinion, however, as research shows that men, and people who are already politically engaged, are the most frequent users of interactive features of news sites (Chung 2008), while online news commenters tend to be the most opinionated of readers (Lee 2012). In addition, YouTube videos are often shared between people within existing social networks and so neither readership nor viewership is random or representative. By combining comments from YouTube and the two different news sources, we have sampled the diversity of Victoria Grant's audience, but we can make only limited assumptions about this audience; for example, most (not all) present themselves as adults and, based on their comments, most seem to be Canadian or American. Given that we cannot generalize from our sample of comments, the most interesting avenue for analysis is to explore the discursive character of political conversation and the strategies people use to advance their positions.

Because commenters' public personas often provide clues about their gender identities, age, nationality and politics, which are connected to their arguments, we make reference to online users' pseudonyms. Some online researchers argue that pseudonyms should be omitted to further conceal the identities of people who have not consented to participate in research (Lamb et al. 2013). In our view, online pseudonyms already afford users a chosen degree of anonymity and their inclusion in research is appropriate given that the comments are in the public domain.

To capture responses to Victoria Grant's speech, we selected the first 150 posted online comments from the two stories in the national news media: the Huffington Post Canada's "Victoria Grant, 12, Hits Lecture Circuit To Explain How Canadian Banking Is A Fraud" (May 15, 2012) and the CBC's "12-year-old Blasts Canada's Banks: Victoria Grant's Critique of Financial System Goes Viral" (May 16, 2012). At the time of sampling, these stories had generated 354 and 343 comments respectively. We also identified the three postings of the video on YouTube that had the highest view counts. Each posted video had received between 100,000 and 650,000 views and a combined total of 2,214 comments at the time of our analysis. For each YouTube video we selected the first 50 comments and another 50 that appeared ten days later, after the video had presumably reached a wider online audience. These decisions resulted in a total sample of approximately 600 comments (178 singlespaced pages) from the two mainstream news sources and the three copies of the video on YouTube.

We analyzed the comments following procedures for qualitative content analysis recommended by Mayring (2000) and Altheide and Schneider (2013). Our method involved three distinct phases of analy- 
sis: code generation through a process of close reading, systematic coding with the aid of qualitative data analysis software, and interpretation. The two authors worked independently with the complete data set during preliminary and systematic coding, coming together after each task to discuss emerging findings. Interpretation involved writing analytical memos about the 22 most theoretically relevant codes. These memos combined descriptive analysis, such as frequencies and matrices, with critical discourse analysis, and included selections of illustrative text. Interpretive analysis finally involved grouping the codes, and reflecting on their relationships, to identify four themes. The first three themes discuss dominant representations of childhood, focusing on 1) education and becoming, 2) children as (selectively) competent or incompetent, and 3) innocence (and therefore vulnerability). Within each of these themes we draw out the complexity of discourses of childhood, and their relationship to participation. Each of these themes is fraught with contradiction, although overall they undermine the authority of children's political speech. The final theme examines rhetorical patterns related to age, gender and newsworthiness.

\section{Theme 1: Education}

A focus on children's development, socialization or their process of becoming, resonates with the position that young people are in the process of learning to be citizens (see Lister 2007; Roche 1999), and is also reflected in the centrality of informal and formal education in children's lives. Education was frequently addressed by the commenters on Victoria Grant's speech. Victoria Grant's education is credited for allowing her to become a competent speaker on banking reform, but she is largely positioned as a passive recipient of this education, perhaps even a victim of indoctrination. It is not until she becomes an adult that she will be a fully bona fide critical thinker and political speaker.

Prominent within commentary on Victoria Grant was discussion of how she was educated, reminding us of how certain kinds of children's participation are linked to class privilege (Vandenbroek and Bourvernede-Bie 2006). Most commenters emphasized either the role of her parents, primarily her father, or her private school. Eight praised her parents for educating her well enough that she could make a speech about economics, one cynically adding, "unlike most of these so-called parents these days" (VexT916, YouTube2) and several others were inspired to teach the same thing to their child(ren). These comments attribute the strength of Victoria Grant's speech to her parents' skills more so than her 
own, thus transferring her competence to her parents. In contrast, a few others merged recognition of her parents' influence with Victoria Grant's own agentic capacities.

If you haven't already you should check out some of the follow up interviews with Victoria about her speech. She does seem to understand what her speech is about. I agree that her father seems to have had an influence in her world view as many of our parents have. I am still impressed to see that a 12 year old girl has an interest in something other than pop culture! (Vginy69, Youtube3).

Comments such as this noted that Victoria Grant was well-guided, but then appreciated that she embraced her topic. This observation resonates with the on-line comments from Victoria Grant's father who explained that while banking reform is an interest of his, Victoria Grant is bright, wanted to learn more and to think through what she was taught, and was supported in this interest. Notably, Victoria Grant did not self-identify as a participant in this on-line discussion, however, and her position is thus mediated by her father.

Second to discussion of the parental role in education was discussion of Victoria Grant's formal schooling. While some defended public education, more criticized it, assuming that Victoria Grant could not have been schooled through the public system, a system seen as inadequate and untrustworthy. Victoria Grant's father corroborated this assumption, posting that Victoria Grant's private school encourages public speaking.

These debates about the role of her parents and about public versus private education soon transformed into concerns about indoctrination, leading commenters to argue back and forth about who indoctrinates (e.g. those on the Right or those on the Left), and how indoctrination and education are inter-related. Of course this whole debate was against the back-drop of contentions that Victoria Grant had been indoctrinated, primarily by her parents, and was therefore unable to think for herself. As calabrain (CBC) most directly stated: "She is just mimicking those who taught her how to think and what to say." Within all of these arguments, Victoria Grant herself was conceptualized as vulnerable to exploitation, with no will or critical capacities of her own, a point we elaborate in Theme Three: Innocence. With some exceptions, in these discussions of education Victoria Grant seemed almost incidental, as a mere vessel that was being filled by adults: a child in the process of being shaped.

The dominant conception of education as a process of shaping and improving also tended to undermine Victoria Grant. A focus on what she was going to become arose implicitly through comments on her education but also explicitly when people focused on what she will become in 
the future, rather than her, or her message, in the present. For example, one said: "As she works her way through school, she's got a great start in critical thinking skills" (lisa321, CBC) and another that she "is going to excel at [critical thinking]" (C_Scrutinizer, CBC). Four stated that Victoria Grant is "promising" or has a "bright future". Some even hypothesized future employment for Victoria Grant, as a politician, broadcaster, or financial leader. While positive, these can all also be considered backhanded compliments in a way, as they imply that she is not yet thinking critically or thinking for herself, disregarding the authenticity of her speech as a powerful one that had wide circulation.

Only a minority of comments on education positioned Victoria Grant as agentic, desiring and capable. These talked about how Victoria Grant "knows her material" (Scott Baker, Huffington) and that she has a cultivated, "enquiring mind" (Sandra Lee Jeffrey, Huffington). As mags83 (Huffington) summarized: "Give Tori a break... and some credit. She educated herself." Such affirming comments were infrequent among the postings, however. Instead, childhood was mainly articulated within a discourse of "becoming", in a way that sociologists of childhood have criticized for obliterating any sense of children as active social participants in the present (Prout and James 1997): Victoria Grant is still "in process", a process crucially guided by adults. As well as positioning children as unable to independently contribute to political or economic conversations in the present, these narratives imply that adults themselves are independent thinkers, no longer in the process of being educated, and free of indoctrination, denying adult interdependencies and on-going change (Lee 2001).

\section{Theme 2: In/COMPETEnCE}

A second central narrative to many comments on Victoria Grant's speech pertained to her competence or incompetence. Forty-three different people made comments that we categorized under "child competence," suggesting that Victoria Grant is able, and therefore eligible, to address Canada's banking system. Some of these engaged seriously with her ideas and de-emphasized her age, whereas others felt that she had to be an exceptional child. In contrast, an almost equal number of commenters either directly discredited Victoria Grant's speech or undermined Victoria Grant herself by emphasizing that, as a child, she is incompetent: they doubted that children could grasp economic material and consequently questioned Victoria Grant's expertise. 
Children and adults are similar, and competent, legitimate participants in political discussion

A small number of commenters referred to Victoria Grant primarily as a person rather than as a child. They did this in several ways. Seven engaged positively with what she was arguing without addressing her age at all, suggesting that she had a "most excellent speech!" (crazeyspivey, Youtube1) or "excellent advice" (smalltownsask, CBC). They took her argument seriously and agreed with it. Eight objected to others' commentary about Victoria Grant's age, wanting to discuss the substance of her speech, either positively or negatively, instead. There were even a few who argued that we should think about children as persons, much as we think about adults. For example, Conspiracybob (Youtube2) uniquely argued that children have rights, and SteveC100482 (YouTube2) suggested that what is important here is not that Victoria Grant is a child but that she is a person who is trying to improve things.

Other commenters who embraced Victoria Grant's competence recognized her age, but generally believed children to be smart and capable. Eleven emphasized that many children have the capacity to understand complex ideas. As one respondent said, "Any 12 [year old] with smarts, the Internet and the ability for public speaking could pull off what Victoria Grant did." (GrumbleBear, CBC). Six recalled being similar to Victoria Grant: a "smart kid", an avid reader, intellectually self-confident and curious, even "desperate" for explanations of things that interested them. These recollections of childhood selves were presented to normalize Victoria Grant's competence and to affirm her agency. If they were like her when they were 12 , others should believe that she, like other children, is capable of understanding her speech and being genuinely interested in her topic.

Finally, three commenters affirmed Victoria Grant's competence through identifying themselves as children. As Lone wolf (YouTube3) wrote, "score she's my age [happy emoticon]." Similarly, Josh Nazer (YouTube2), after commenting substantively about government and CEO accountability to the public, added "P.S. I'm 12 as well." These comments belie the assumption that children are disinterested in, or incapable of, contributing to political debates. As most commentary made Victoria Grant, and 12 year-olds generally, into objects of adult analysis, the presence of these few children's voices highlights the absence of children's voices on the whole.

Amongst all the comments that we reviewed, it was the participants who engaged with Victoria Grant's argument directly without highlighting her age and those who emphasized children's capacities, in part by 
identifying with Victoria Grant, who most directly supported children's general abilities and voice, but this group was in the minority.

\section{Children like Victoria Grant shame adults, especially our leaders}

Related to children's competence, another strain of comments privileged children with insights that transcend those of particular adults. For example, 38 commenters were inspired by Victoria Grant's speech to make a jab at political, business or banking leaders, including "Ottawa” (12), the Prime Minister (7), the Finance Minister (7), the governing party (3), the governor of the Bank of Canada or leaders in the banking industry (6), opposition leaders, economists, or the "establishment" generally. Other comments indirectly shamed leaders by arguing that Victoria Grant deserved to run for office, or even to become the President of the U.S.! These messages refer specifically to her age or gender to point up the inferiority of political and economic leaders:

This young lady certainly has a better grip on foundational economic issues than Flaherty and Harper - two men who proport (sic) to be economists but in fact know nothing about economics! (Keon Fan, CBC).

Similarly, 43 enthusiastically supportive comments suggested that Victoria Grant's speech on banking reform reflected negatively on adults in general. JRCrowley (Youtube1) was most direct: "She probably understands it better than $90 \%$ of the fucking nitwit, dumbed-down, high-fructose corn syrup sucking, TV watching adult morons out there, yes."

These admirers of Victoria Grant variously characterized adults as ignorant, lacking critical thinking, sheep-like, lazy or criminally complicit in a corrupt economic system. Such supporters commended Victoria Grant as capable of addressing important economic and political questions, yet they did so while criticizing leaders specifically, or adults generally, by negatively comparing them to children, as if that is the pinnacle of humiliation. Thus many of Victoria Grant's supporters backhandedly undermined children's capacities.

An exception to this more negative framing, 22 commenters positioned Victoria Grant as emblematic of her generation, either because her generation is particularly affected by current monetary policy and the burden of debt or because of more generalized intergenerational conflict. These commenters found it apt that Victoria Grant voice the call for banking reform because of her youth, particularly when adults were not seen to be living up to their responsibility towards young people and safeguarding their future. 


\section{Victoria Grant's competence is exceptional}

Another pattern was for commenters to accept Victoria Grant's competence but to frame it as exceptional, thus undermining other children's capacities. Eight emphasized that Victoria Grant was unique in her engagement with questions in the wider world and expressed some surprise that a young girl would be interested in these things. A further eighteen specifically framed Victoria Grant as a great critical thinker, particularly insightful, very smart, gifted, brilliant, or more caring than most. These commenters tended to be excited by Victoria Grant's speech, taking it seriously and embracing the capacities and views of this one young person. Yet in order to raise Victoria Grant up, they drew on assumptions about young people that dismiss their capacities and interests more generally: what is so remarkable about Victoria Grant and her speech is that she is not like other twelve-year-olds because most twelve-year-olds are not interested or competent.

\section{Children cannot grasp economics}

Indeed for eleven others, it does not matter what Victoria Grant is arguing, a 12-year-old cannot know what she is talking about: "You do remember she's 12 right? And knows nothing about reality, responsibility or really... anything?" (jasgil, CBC). And mrgayness (CBC) suggested that her solution was simplistic, and thus a "typical 12 year old". Even among five of the commenters who viewed Victoria Grant as gifted, there was doubt because of her age. As notoilfan (CBC) declared, "I don't care how high her IQ is or how eloquent she is. The fact is she is a 12 year-old girl. She doesn't know squat." Such arguments undermined Victoria Grant's entire speech on the basis of her age alone.

Similarly, others supported Victoria Grant's speech, and yet presumed children's incompetence by arguing that her argument is simple. Six comments reflected bowenjuice (Youtube3) who wrote, "the problem with our economy is so simple even a 12 year-old can understand it." Other comments that we coded as "child incompetence" took this theme further, more exclusively suggesting that children do not care about these things. As Lagolop (Youtube1) bluntly put it, "It's very hard to believe that a kid so young would give a rats ass about this shit."

On what grounds can Victoria Grant be understood to be competent to speak about economic issues? Some of those who questioned Victoria Grant's message believed that she could not yet have the requisite expertise: "she is only 12 and how is she even a expert (sic)" (Charles the Great, Huffington Post). As SidelineBoy (Huffington) also stated, "She has no clue, no frame of reference and no experience borrowing 
money, earning a living or anything else to do with adult life." These kinds of comments resonated with those positioning Victoria Grant as a pawn of her parents (primarily her father) because she could not possibly have learned and understood the material herself. Expertise depends on having time to study, as well as life experience, which Victoria Grant is too young to have acquired. Those critical of Victoria Grant similarly argued that economics is a complex field in which experts typically rely on educated predictions, so how could Victoria Grant possibly be sufficiently educated? Often in making these arguments, people asserted their own expertise (whether or not they agreed with Victoria Grant), claiming to have formal education in economics, work experience in banking, or the title of economist, all of which would preclude Victoria Grant from being similarly knowledgeable. Nine commenters made fun of Victoria Grant's age and inexperience:

Oh, you just have to see her video that solves world hunger and the other one that provides the solution to conflict in the Middle East. Those are about to go viral (Think4YourSelf1, CBC)

$* * *$

I'm waiting for the Etrade baby to do it and also a dog, but I want a smart dog (or at least looks smart, maybe put glasses on him). Would have a lot of believers. (LetsKeepitSimple, Huffington).

These comments mocked Victoria Grant's optimism for social change but also any child's ability to comment on financial issues, or any issue at all.

Based on such negative assessments of Victoria Grant's age and experience, many concluded that she is a fake. They argued that her speech was really her father's, and that she memorized it for her school assignment without understanding it. If a child cannot possibly understand economics, as many clearly felt, then a logical next concern is about exploitation. In contrast to comments that either positioned Victoria Grant as competent like other children or uniquely competent among children, or that undermined Victoria Grant by questioning her age and skills or by laughing at her due to her age (and possibly gender), a smaller number of people posted very concerned missives about her exploitation, raising another current discourse of childhood: innocence. 


\section{THEME 3: INNOCENCE}

Innocence is linked to naiveté, playfulness, ignorance, and lack of experience. It positions children as particularly vulnerable and therefore needing valuable protection, although it can also contribute to children's marginalization (Robinson 2013; Johnny 2006; Stasiulis 2002). While innocence was not the most dominant lens in the on-line comments, it certainly emerged in a large number of comments, as either a privileged or vulnerable location, and was linked to concerns about the plight of Victoria Grant.

\section{Wise child}

There were seven commenters who more or less used the words "from the mouths of babes," and ten more who otherwise elaborated on the theme that innocence provides sheltered insight. A few even alluded to Biblical themes of liberation: "And a child shall set them free" (FreedomLady10, Huffington). These commenters positioned Victoria Grant as a prophetic figure representing the age-old wish for, and Christian promise of, salvation not only from personal sin, but in this context, from social injustice.

The "from the mouths of babes" theme is larger than the Christian interpretation, however. Reflecting Rousseau's assertions about childhood innocence, some commenters suggested that children are inherently wise, and have a closer grasp of the truth because they have not been corrupted or compromised by age and schooling. For example, Occ192 Ossie (CBC) claimed that children are "always direct, honest and sincere" and TheRenaissanceMan (Huffington Post) said, "Children always have the best perspective. They have 'new eyes' that can spot bullcrap a mile away." For this reason, adults should listen to children such as Victoria Grant. Further, if childhood innocence provides a unique, untainted lens into the workings of politics or economics, growing up is a source of corruption:

And 10 years from now, she'll be in the field of finance. And part of the very corruption that she's supposedly fighting against (gommerthus, Huffington)

Again the philosophy of Rousseau lives on in such laments about the evils of society gradually shattering children's innocence. Among commenters, corruption was seen to come specifically through greed, popularity, capitalism and brainwashing through formal education. If innocent children's voices provide valuable, privileged insight, lack of experience is not a liability, but rather an asset: we should listen to Victoria Grant. 
But innocence is also linked to being carefree and vulnerable, traits that led others to counter that Victoria Grant should not be commenting on economics at all.

\section{Childhood as carefree and non-political}

[This] 12 years old ... speaks of things that she should not even know they exist. She should play and enjoy because once you get into adulthood there is no way back (puujdo, YouTube2).

Even though the political realm certainly affects the lives of children, to commenters like puujdo, innocence is about playful ignorance. While only a small number of commenters directly framed Victoria Grant's innocence in this way, these concerns linked to broader worries about Victoria Grant's indoctrination or exploitation. If children are inherently innocent and non-political, then their political speech must come from adults, and children such as Victoria Grant are being used as pawns and thus being exploited. All of these arguments were linked to a desire to better protect Victoria Grant; they were also thick with moral disapproval of how commenters saw adults (especially her parents) using Victoria Grant. Overall there were 75 comments that in some way connected to this idea of exploitation.

Most dominantly, people were concerned that Victoria Grant was being used as a vehicle for expounding her parents' political views. Descriptions of Victoria Grant's position included puppet (5), parrot (2), poster child (2), advertisement (2), gimmick, megaphone, shill, adorable monkey, and daddy's little girl. Some of these comments were general, or neutral, simply saying that others were behind what Victoria Grant had to say. But there was also strong criticism from some. As RedSoxPhil37 (YouTube2) demanded: "don't use your kids to proselytize." Equating a 12 year-old girl with small children, ArcticDude (CBC) and Alberto66 (Huffington) compared Victoria Grant's parents' motives to those of parents on the reality TV show, Toddlers and Tiaras. Johnny Utah (CBC) agreed: "This ranks up there with child "porn' pageants... disgusting..."

Nine expressed very strong moral offence, believing Victoria Grant to be exploited or manipulated. Instrumentals4Sale (Youtube2), made this argument several times, arguing that:

To dictate a political message to a child and then have them 'perform' that message around the country has nothing to do with education $\&$ is just a (kinda sick) form of manipulation... it manipulates the viewer who feels empathy with a child instinctively but even worse it manipulates the child for the benefit of the movement/event. 
Another suggested that this is an "example of child abuse" (MrZebos, Youtube1), in part because it will be an embarrassment for Victoria Grant in the future. Thus, Victoria Grant is a victim of adults and is not in a position to consent to making such as speech.

All of these comments imply that Victoria Grant herself lacks will, agency and desires of her own. The speakers are concerned for Victoria Grant, but in a way that suggests children should never have a say in the economic/political arena. The focus is on wanting to protect and regulate children, with children's welfare rights trumping participation or selfdetermination rights (Wyness et al. 2004). Such depictions of childhood are likely also related to Victoria Grant herself, as a young, white girl. Concerns about the exploitation of innocence are not always so rigorously applied to Other children, such as non-white boys (Goff et al., 2014).

\section{Theme 4: Rhetorical Strategies}

In our analysis so far, we have examined contradictions within dominant cultural discourses of childhood, discourses through which commenters argued and made sense of Victoria Grant's speech-making ability and interest in banking reform. In this final theme, we underscore the elasticity of these representations of childhood by foregrounding the politics of their construction and contestation. Through the on-line commentaries, a variety of everyday ways of speaking about gender, age and the news were mobilized as rhetorical strategies through which participants advanced a position in the debate.

\section{Gender}

Selecting all the comments that made reference to Victoria Grant's gender and age, we looked for patterns according to whether the author spoke in ways that supported her speech because of its content, because it was delivered by Victoria Grant, or both. Among these positive comments, "girl" was the most common gender descriptor, and was used matterof-factly. Some calling her a girl emphasized that she is smart, bright, spunky or brilliant. Some noted her actual age in the same matter-of-fact manner, which seemed to reinforce her competence: "This 12 year old girl's speech is a wakeup call to everyone to pay attention and self-educate sooner than later" (TroyAB, CBC). Another group of commenters supportive of her speech called her a "young lady," a term used with respect and which tended to elevate her. For example, theboyfrommiddlesbro (YouTube2) said, "Victoria - you Rock young lady," while other "young lady" comments similarly called her smart, articulate or brilliant. 
An equal number of commenters used familial language ("Preach it Sister!" MichaelH, CBC) or terms of endearment (sweetie, good girl, baby girl and dear), which can also be considered condescending.

Among those who were more negative about Victoria Grant and the contents of her speech, fewer referred to her matter-of-factly as a girl. "Girl" sometimes became more editorialized, for instance, when paired with something else, such as "young girl" or "school girl". As topshelf01 (CBC) said, "Watch out Lagarde [Director of the International Monetary Fund] school girl's coming for you." The majority of the negative gender comments referred to Victoria Grant as a "little girl" who does not know what she is talking about or is a pawn of her parents. "Little girl" accentuated her youngness, but also, her girlness.

A few other comments dismissed Victoria Grant's arguments by objectifying her in gendered, sexualized ways: "small boobs" (dylannylund, YouTube3), "yummmm” (Lolic0nz, YouTube2), "So smart! And cute too!" (jim82long, YouTube1). Two additional sexist comments rebuked her for not being more domestic and subordinate: "Show her the kitchen now" (redhotbits, YouTube2) and "This girl will grow up to be a nice housewife cooking in the kitchen" (revolutionaryjake, YouTube1). Such attacks on the rights of girls and women to speak was at the extreme end of a more widespread tendency for Victoria Grant's girlness to be exaggerated, or infantalized, among those who disagreed with her speech. In this way discrimination around gender, combined with age, was a tactic to weaken Victoria Grant's position, to concomitantly strengthen the position of the adult commenter, and to reinforce the view that economics is the domain of adult men.

Age

As we have illustrated, a range of age markers were used in reference to Victoria Grant. The comments supporting her argument were more likely to call her a "young lady", or matter-of-factly, a "12 year-old", a " 6 th grader", and a "kid". One of the positive age-related comments emphasized personhood over age: "Victoria, thank-you for telling Canada that small people can make a difference" (smalltownsask, CBC).

Those less supportive of her arguments, in contrast, often emphasized her status as a young child. "Little girl" was more than twice as prevalent among the negative remarks than the positive, especially among those who saw Victoria Grant as a pawn: "These ideas OBVIOUSLY didn't come from that little girl" (corradi3, YouTube1); "just being daddy's little girl" (Instrumentals4sale, YouTube2). Those who disagreed with her arguments were also the ones to make fun of her age. Some of the 
mockery positioned her as a "little tyke" or baby, and was sarcastic: "I often go to twelve year olds for financial advice" (DanSc, Huffington).

Others countered these age references, however, arguing that Victoria Grant's age is not the important story and wanting to discuss the substance of the speech. Some suggested that to focus on Victoria Grant's age was to apply an unfair double standard. After all, people would not similarly question the competence of their "favourite politician, TV anchor or star" (McDoulgham, YouTube2). But Victoria Grant's age was relevant to many. As SidelineBoy (Huffington) retorted, the story is crucially about her age: "If I'm suppose (sic) to be enthralled with this young prodigies (sic) intelligence, then I'd like to know who she is, how she came up with this, and whether or not she understands something that most adults don't."

\section{Newsworthiness}

Opinions about whether Victoria Grant's speech should have been in the news at all also hinged on notions of childhood and again reflected commenters' banking politics. Five people said that this was not news, one even scathingly suggesting that $\mathrm{CBC}$ reporters seem to be pointlessly surfing Youtube for news. Others (11) countered that the speech is an important news story and that the naysayers had missed its point about banking reform. Three of these were critical that the story had been relegated to the "off-beat" section of CBC's news, and one added that this story should have been developed into a larger story about public banking. However, those seeking to promote the substance of Victoria Grant's speech seemed limited in their rhetorical moves, typically opting to downplay her age and argue that one should focus on the message not the speaker. Only one commenter drew a comparison to another young orator, Severn Cullis-Suzuki's 1992 speech to the UN's Earth Summit at age 12 , whose message was newsworthy by virtue of its strong political message pointed directly at adults. With a few exceptions such as this, supporters of Victoria Grant's message seemed unable to draw on more positive discourses of children's participation.

\section{Can a Child Speak About Economics?}

Through examining the on-line responses to Victoria Grant's speech on banking reform we see significant diversity in how childhood is conceptualized: through complicated engagements with education, competence, incompetence and innocence, all fraught with contradiction and all linked also to the political positions of the commenter. One implication 
of this diversity is that discourses are selectively deployed in response to young people's participation in political debates. In our discussion of rhetorical strategies, we see that people are more likely to position Victoria Grant as an incompetent girl and/or child, for example, when they disagree with what she is saying.

Within this diversity, discourses positioning children as voiceless are stronger than those recognizing children as social participants or agents who have legitimate voices. Most dominant conceptualizations of children, e.g., as becoming or as incompetent, tended to discredit children's commentary. Childhood innocence was a little more complicated as for some it conjured up a child's insight that is unavailable to adults, yet innocence at the same time calls for children's protection, including protecting their carefree playfulness. Ironically, if children see and comment on the "truth" to which they have privileged access, they can be seen to be losing the very innocence providing them with that insight in the first place. Despite more international and academic emphasis on children as valuable and able social participants who have the right to be taken seriously (James 2009; Wyness 2006; Kehily 2004), there was a noteworthy paucity of commenters referring to children's rights to participation, suggesting that the discourse of children as active and participatory beings in the present has not really entered popular North American consciousness, at least when it comes to discussing economics on-line. Notably, this absence is evident even for a child like Victoria Grant, who occupies significant privilege compared to many other children.

As discourses produce our subjectivities, shape what we see as possibilities, and contribute to how we act towards ourselves and others, the complicated interweaving of discourses we have examined here produces a net that largely prevents children from being understood as agentic and participatory beings, at least in what is largely considered an adult realm of society: the economics and politics of banking. Yet even in the face of such a tightly woven discursive net, there were also commenters who spoke "meaningfully and convincingly beyond the terms of their subjection" (Laws and Davies 2000: 206). For instance, there were commenters who reflected on their own childhood selves' experiences of insight and intelligence to respond to the more dominant comments on children's incompetence and innocence, and three commenters who were children themselves. Furthermore, Victoria Grant herself, while noticeably not a participant in the on-line comments, confidently presented herself, through her speech, as an informed and appropriate participant in conversation about banking reform. Finally, through on-line argument, and through analyses like this one, we can identify rival discourses of childhood that counter and potentially undermine each other, suggesting 
that there is no singular story of childhood participation. We can identify how discourses of childhood are assessed and compared, sometimes creating further openings for prioritizing children's voice.

\section{REFERENCES}

Altheide, David L., and Christopher J. Schneider. 2013. Qualitative Media Analysis, Second edition. Thousand Oaks, CA: Sage.

Black, Rosalyn. 2011. Student participation and disadvantage: limitations in policy and practice. Journal of Youth Studies 14(4): 463-474.

Burman, Erica. 2001. Beyond the baby and the bathwater: Postdualistic developmental psychologies for diverse childhoods. European Early Childhood Education Research 9(1): 5-22.

Butler, Judith. 1997. The Psychic Life of Power. Stanford, CA: Stanford University Press.

Butler, Judith. 1992. Contingent foundations: Feminism and the question of "postmodernism". In Feminists Theorize the Political, edited by Judith Butler and Joan W. Scott, 3-21. New York, London: Routledge.

Burr, Vivian. 1995. An Introduction to Social Constructionism. London: Routledge.

Christensen, Pia and Allison James, editors. 2008. Research with Children: Perspectives and Practices. London: Falmer Press.

Chung, Deborah S. 2008. Interactive features of online newspapers: Identifying patterns and predicting use of engaged readers. Journal of ComputerMediated Communication 13(3): 658-679.

Davies, Bronwyn. 1990. Agency as a form of discursive practice. A classroom scene observed. British Journal of Sociology of Education 11(3): 341361.

Goff, Phillip Atiba, Matthew Christian Jackson, Brooke Allison Lewis Di Leone, Carmen Marie Culotta, and Natalie Ann DiTomasso. 2014. The essence of innocence: Consequences of dehumanizing black children. Journal of Personality and Social Psychology 106(4): 526-545.

Gruber, Helmut. 2008. Analyzing communication in the new media. In Qualitative Discourse Analysis in the Social Sciences, edited by Ruth Wodak and Michal Krzyzanowski, 54-76. Palgrave Macmillan.

Imre, Robert and Zsuzsa Millei. 2010. Citizenship? What citizenship? Using Political Science terminology in new discipline approaches. In (Re)Theorizing Discipline in Education: Problems, Politics and Possibilities, edited by Zsuzsa Millei, Tom G. Griffiths and Robert John Parkes, 131-145. New York: Peter Lang Publishing, Inc. 
James, Allison. 2009. Agency. In The Palgrave Handbook of Childhood Studies, edited by Jens Qvortrup, William A. Corsaro and Michael-Sebastian Honig, 34-45. Palgrave Macmillan.

Johnny, Leanne. 2006. Reconceptualizing childhood: Children's rights and youth participation in schools. International Education Journal 7(1): 17-25.

Kallio, Kirsi Pauliina and Jouni Häkli. 2011. Tracing children's politics. Political Geography 30(2): 99-109.

Kehily, Mary Jane (2004) Understanding childhood: An introduction to some key themes and issues. In An Introduction to Childhood Studies, edited by Mary Jane Kehily, 1-21. Maidenhead: Open University Press/McGraw Hill.

Lamb, Sharon, Kelly Graling, and Emily E. Wheeler. 2013. 'Pole-arized' discourse: An analysis of responses to Miley Cyrus's Teen Choice Awards pole dance. Feminism \& Psychology 23(2): 163-183.

Lansdown, Gerison. 2001. Promoting Children's Participation in Democratic Decision-Making. Unicef, Innocenti Research Centre, Florence, Italy.

Lansdown, Gerison. 2010. The realization of children's participation rights: Critical reflections. In A Handbook of Children and Young People's Participation: Perspectives from Theory and Practice, edited by Barry Percy-Smith and Nigel Thomas, 11-23. New York: Routledge.

Larkins, Cath. 2014. Enacting children's citizenship: Developing understandings of how children enact themselves as citizens through actions and Acts of citizenship. Childhood 21(1): 7-21.

Laws, Cath and Bronwyn Davies. 2000. Poststructuralist theory in practice: working with "behaviourally disturbed" children. Qualitative Studies in Education 13(3): 205-221.

Lee, Eun-Ju. 2012. That's not the way it is: How user-generated comments on the news affect perceived media bias. Journal of Computer-Mediated Communication 18(1): 32-45.

Lee, Nick 2001. Childhood and Society: Growing up in an Age of Uncertainty. Buckingham: Open University Press.

Lister, Ruth. 2007. Why citizenship? Where, when and how children? Theoretical Inquiries in Law 8(2): 693-718.

Masschelein, Jan and Kerlijn Quaghebeur. 2005. Participation for better or for worse? Journal of Philosophy of Education, 39(1): 51-65.

Mayring, Philipp. 2000. Qualitative content analysis. Forum: Qualitative Social Research, 1(2). Accessed at: http://nbn-resolving.de/urn:nbn:de:0114fqs0002204 December 30, 2014.

Millei, Zsuzsa. 2010. Is it (still) useful to think about classroom discipline as control? An examination of the "problem of discipline". In Re-theorizing Discipline in Education: Problems, Politics and Possibilities edited by Z. Millei, T. Griffiths, T., and R.J. Parkes, 13-26. New York: Peter Lang. 
Park, Augustine S.J. 2013. Racial-nationalism and representations of citizenship: The recalcitrant alien, the citizen of convenience and the fraudulent citizen. Canadian Journal of Sociology 38(4): 579-600.

Pongratz, Ludwig. 2007. Freedom and discipline: transformations in pedagogic punishment. In Why Foucault? New directions in educational research, edited by Michael A. Peters and Tina Besley, 29-42. New York: Peter Lang.

Prout, Alan and Allison James. 1997. A new paradigm for the sociology of childhood? Provenance, promise and problems. In Constructing and Reconstructing Childhood: Contemporary Issues in the Sociological study of Childhood, edited by Allison James and Alan Prout, 7-33. London: Falmer Press.

Raby, Rebecca. 2014. Children's participation as middle class governance? Discourse: Studies in the Cultural Politics of Education 35(1): 77-89.

Reynaert, Didier, Maria Bouverne-de Bie and Stijn Vandevelde. 2009. A review of children's rights literature since the adoption of the United Nations Convention on the Rights of the Child. Childhood 16(4): 518-534.

Robinson, Kerry. 2013. Innocence, Knowledge and the Construction of Childhood: The Contradictory Nature of Sexuality and Censorship in Children's Contemporary Lives. Routledge.

Roche, Jeremy. 1999. Children: rights, participation and citizenship. Childhood 6(4): 475-493.

Skott-Myhre, Hans and Danny Tarulli. 2008. Becoming-child: ontology, immanence, and the production of child and youth rights. In Children's Rights: Multidisciplinary Approaches to Participation and Protection, edited by Tom O'Neill and Dawn Zinga. Toronto: University of Toronto Press.

Stasiulis, Daiva. 2002. The active child citizen: Lessons from Canadian policy and the children's movement. Citizenship Studies 6(4): 507-538.

Such, Elizabeth and Robert Walker. 2005. Young citizens or policy objects? Children in the "rights and responsibilities" debate. Journal of Social Policy 34(1): 39-57.

Taylor, Carol A. 2011. "Hope in failure": A Level students, discursive agency, post-feminism and feminism. Gender and Education 23(7): 825-841.

Vandenbroeck, Michel and Maria Bouverne-De Bie. 2006. Children's agency and educational norms: A tensed negotiation. Childhood, 13(1): 127-143.

Walkerdine, Valerie. 1993. Beyond developmentalism? Theory and Psychology 3(4): 451-469.

Woodhead, Martin. 2005. Excerpts from early childhood development: A question of rights. International Journal of Early Childhood 37(3): 79-98.

Wyness, Michael. 2006. Childhood and Society: An Introduction to the Sociology of Childhood. Basingstoke; New York : Palgrave MacmillanT 
Wyness, Michael, Lisa Harrison and Ian Buchanan. 2004. Childhood, politics and ambiguity: Towards an agenda for children's political inclusion. Sociology 38(1): 81-99.

Zelizer, Vivian. 2005. The priceless child revisited. In Studies in Modern Childhood, edited by Jens Qvortrup, 184-200. Basingstoke: Palgrave Macmillan.

Rebecca Raby is a Professor in the Department of Child and Youth Studies at Brock University. Her research draws on post-structural and critical theories to examine shifting constructions of childhood and adolescence, and how these are intersected by gender, race, class and sexuality. She is the author of School Rules: Obedience, Discipline and Elusive Democracy (2012) and co-editor of Power and Everyday Practices (2012). Based on a recently completed SSHRCfunded research, she is currently writing Smart Girls: Academic Success in a Post-Feminist Era with Dr. Shauna Pomerantz.

rraby@brocku.ca

Mary-Beth Raddon is an Associate Professor in the Department of Sociology, and Graduate Program Director of Social Justice and Equity Studies at Brock University. Her research interests in monetary politics focus on understanding historical and contemporary social movements for, and models of, local and regional currencies and public banking. She is the author of Community and Money: Men and Women Making Change (2003).

mraddon@brocku.ca 
188 (c) Canadian Journal of Sociology/Cahiers Canadiens de Sociologie 40(2) 2015 